\title{
IDENTIFIKASI FAKTOR PENYEBAB PERILAKU BULLYING DI PESANTREN: SEBUAH STUDI KASUS
}

\author{
Sigit Nugroho ${ }^{1}$, Seger Handoyo ${ }^{2}$, Wiwin Hendriani ${ }^{3}$ \\ ${ }^{1}$ Mahasiswa Doktoral Fakultas Psikologi, Universitas Airlangga, Indonesia \\ ${ }^{2,3}$ Fakultas Psikologi, Universitas Airlangga, Indonesia. \\ e-mail: sigit.nugroho@psy.uir.ac.id
}

\begin{abstract}
Bullying has become an international problem in as much as it has some serious impacts on academic conditions, psychological well-being, healthy and life safety for victims, spectators and bullies. The most serious danger from bullying is many of victims and spectators transforming to become the bullies of bullying. The existing theoretical studies are generally non-boarding public schools. Apart from the reasons that have been explained in the existing theory, the writer wants to see if there are specific factors in the pesantren environment that cause bullying behavior. The aim of this study is to identify what factors contribute for changing from victim or witness to be a perpetrator in Islamic boarding schools where Indonesian Islamic boarding schools are perceived as a place where some positive values are taught such as values of virtue, positive behavior, and strong religiosity values. This research used the case study method where participants will be interviewed and data will be analyzed by using thematic analysis. Four participants, man and women, are involved in this research. All of them graduated from Islamic boarding School for one until three years. Individual, families, mass media, Peer group and school environment are factors which contribute to the changing process, from victims and spectators to become bullies. Interestingly, it found some new themes that come outside theoretic themes such as perception to bullying if bullying is only a joke and a tradition among students. They make bullying as compensation for seeking amusement because their academic schedule is so hectic while there are so little academic facilities for dispensing all their exhaustion after learn a whole day.
\end{abstract}

Keywords: bullying, bullying causative factors, bullies, pesantren.

\begin{abstract}
ABSTRAK
Maraknya perilaku bullying atau perundungan di sekolah yang terjadi di berbagai negara menjadikannya sebagai permasalahan internasional yang berdampak serius pada kondisi akademik, kesejahteraan psikologis, kesehatan dan keselamatan jiwa pada korban, penonton dan pelaku. Bahaya yang lebih serius adalah banyak korban dan penonton yang dalam perkembangannya menjadi pelaku bullying. Kajian teoretis yang ada pada umumnya merupakan kajian pada sekolah-sekolah umum yang sifatnya non-boarding. Selain dari sebab-sebab yang telah dijelaskan dalam teori yang sudah ada, penulis ingin melihat apakah ada faktor spesifik yang terdapat dalam lingkungan pesantren yang menjadi penyebab munculnya perilaku bullying. Tujuan penelitian ini mengidentifikasi faktor penyebab menjadi pelaku bullying di lingkungan pesantren sebagai suatu institusi pendidikan Islam khas Indonesia. Pesantren diasosiasikan dengan lembaga pendidikan yang mengajarkan nilai-nilai kebajikan, perilaku positif, dan muatan religiusitas yang kuat. Pendekatan dalam penelitian ini menggunakan pendekatan studi kasus dengan melakukan analisis tematik dari hasil wawancara dengan pelaku bullying di pesantren yang minimal telah satu tahun menjalani pendidikannya dengan jenis kelamin laki-laki dan perempuan. Hasil dari penelitian ini ditemukan lima tema yang menjadi penyebab perilaku bullying di
\end{abstract}


pesantren yaitu faktor individu, keluarga, media massa, teman sebaya dan lingkungan sekolah. Tiga tema, yakni adaptasi siswa baru, persepsi terhadap perilaku bullying yang dianggap sebagai candaan dan tradisi pesantren serta bullying sebagai kompensasi mencari hiburan di pesantren karena padatnya aktivitas belajar dan minimnya fasilitas belajar adalah tema baru yang muncul di luar dari tema teoretis.

Kata Kunci: perundungan, faktor penyebab perundungan, pelaku perundungan, pesantren.

\begin{tabular}{|c|c|c|c|}
\hline FIRST RECEIVED: & REVISED: & ACCEPTED: & PUBLISHED: \\
29 June 2020 & 18 October 2020 & 31 October 2020 & 3 November 2020 \\
\hline
\end{tabular}

\section{PENDAHULUAN}

Pesantren sebagai lembaga pendidikan keagamaan merupakan institusi yang tidak bisa diabaikan keberadaannya. Pesantren merupakan lembaga pendidikan tradisional yang lahir dan tumbuh bersamaaan dengan datangnya Islam ke tanah Jawa. Dengan demikian, pesantren merupakan lembaga pendidikan yang asli (Indegenous) masyarakat Indonesia (Ziemek, 1986). Pesantren merupakan kelanjutan dari sistem pendidikan pada masa Hindu-Budha pra Islam. Dalam sistem pendidikan lama, pesantren berhasil menggabungkan sistem pendidikan yang di dalamnya diajarkan ajaran Islam dengan budaya lokal yang ada pada saat ini. Usaha dalam memadukan antara ajaran Islam dengan budaya lokal merupakan ciri dari awal penyebaran agama Islam, yang mengutamakan toleransi terhadap nilai-nilai yang subuh dalam bermasyarakat sejak Islam sebelum datang (Suteja, 1999).

Bawani (1993) merumuskan beberapa ciri pendidikan di pesantren, yaitu: (1) Adanya hubungan yang akrab antara santri dengan kiai. Kiai memperhatikan sekali kepada para santrinya dan hal ini sangat dimungkinkan, karena sama-sama tinggal dalam satu komplek. (2) Tunduknya santri kepada kiai. Para santri menganggap bahwa menentang kiai selain tidak sopan juga dilarang oleh ajaran agama. (3) Hidup hemat dan sederhana benarbenar dilakukan dalam lingkungan pesantren. Bahkan tidak sedikit yang hidupnya terlalu sederhana atau terlalu hemat sehingga kurang memperhatikan kesehatannya. (4) Semangat menolong diri sendiri amat terasa. Para santri mencuci pakaian sendiri, membersihkan kamar tidurnya sendiri bahkan tidak sedikit yang memasak makanannya sendiri. (5) Jiwa tolong menolong atau persaudaraan sangat mewarnai pergaulan di pesantren. Ini disebabkan, selain kehidupan yang merata di kalangan dihormati, justru dianggap memiliki kekuasaan gaib yang bisa membawa keberuntungan atau celaka.

Hal-hal tersebut di atas adalah nilainilai yang diharapkan tumbuh subur di lingkungan pesantren, namun beberapa penelitian justru menunjukkan kenyataan yang berbeda. Penelitian yang dilakukan Desiree (2013) mencatat adanya berbagai bentuk perilaku bullying yang terjadi di pesantren, seperti bullying dalam bentuk fisik (memukul, menendang), bullying dalam bentuk verbal (kata-kata kasar, ejekan) dan pengucilan. Nugroho dan Fardhana (2018) menemukan bahwa 59\% siswa-siswi pesantren mengaku menerima perlakuan bullying dari temannya.

Penelitian lain yang dilakukan dalam konteks pesantren antara lain penelitian Yani, 
Winarni, \& Lestari (2016). Penelitian ini dilakukan di salah satu pesantren di Jombang. Penelitian ini bertujuan untuk menggali pengalaman santri yang menjadi korban bullying di pesantren, mengeksplorasi perasaan santri saat menjadi korban bullying di pesantren. Dalam penelitian ini ditemukan terdapat tujuh tema yaitu pertentangan menganggu, mendapat perilaku yang menyakitkan dari senior, merasa tertekan, kehilangan motivasi, berusaha mengamankan diri, mencari pertolongan dan tidak menyelesaikan masalah.

Penelitian Simbolon (2012) yang bertujuan untuk mengetahui bentuk-bentuk perilaku bullying, faktor penyebab terjadinya perilaku bullying, dampak perilaku bullying bagi korban, pelaku, dan lingkungan asrama, dan untuk mengetahui usaha yang telah dilakukan pihak institusi dalam usahanya mencegah terjadinya perilaku bullying pada mahasiswa penghuni asrama. Hasil penelitian menunjukkan bahwa bentuk bullying yang terjadi di asrama Universitas A adalah intimidasi, pemalakan, pemukulan, ucapan kotor, dan melecehkan. Didapati pula bentuk perilaku bullying yang ekstrem seperti pemaksaan pada korban untuk menenggak minuman keras, ditelanjangi lalu korban dipaksa mandi tengah malam. Faktor penyebabnya yaitu senioritas, meniru serta pengalaman masa lalu, para pelaku pada umumnya melakukan bullying karena memiliki pengalaman menajdi korban bullying dimasa lampau, sehingga pelaku ingin membalas dendam. Hasil penelitian juga menunjukkan bahwa bullying mengakibatkan korbannya menjadi putus asa, menyendiri, tidak mau bergaul, tidak bersemangat, bahkan halusinasi. Berbeda halnya dengan pelaku, mereka merasa lebih berwibawa dan merasa puas, namun sebagian pelaku juga merasa malu dan minder.

Penelitian Marthunis \& Authar (2017) bertujuan untuk mengetahui persepsi dan intervensi para guru di lingkungan di pesantren modern terhadap bullying. Hasil dari penelitian ini menemukan bahwa guru di pesantren menganggap bullying sebagai perilaku berbahaya yang perlu ditangani. Para guru di pesantren menggunakan beberapa intervensi dalam bentuk pendekatan reaktif daripada proaktif.

Penelitian Finiswati \& Matulessy (2018) bertujuan untuk mengetahui perbedaan kecenderungan melakukan bullying ditinjau dari jenis kelamin dan urutan kelahiran pada santri di pondok pesantren. Hasil penelitian menunjukkan santri berjenis kelamin laki-laki cenderung mempunyai perilaku bullying yang lebih tinggi daripada santri berjenis kelamin perempuan. Selain itu santri yang menempati urutan kelahiran pertama dan terakhir cenderung lebih tinggi dari santri yang menempati urutan kelahiran ditengah.

Dalam penelitian ini penulis melihat bahwa dalam konteks pesantren yang memiliki kekhasan Indonesia dan nilai-nilai spesifik yang dianut dan diajarkan berupa nilai-nilai keislaman yang menekankan pada ajaran tentang akhlak, adanya perilaku bullying menarik untuk dikaji. Secara lebih spesisifik penulis tertarik meneliti sebab-sebab sumber kemunculannya. Kajian teoretis yang ada pada umumnya merupakan kajian pada sekolahsekolah umum yang sifatnya non-boarding. Selain dari sebab-sebab yang telah dijelaskan dalam teori yang sudah ada, penulis ingin melihat apakah ada faktor spesifik yang terdapat dalam lingkungan pesantren yang 
menjadi penyebab munculnya perilaku bullying?

\section{PENGERTIAN PERUNDUNGAN}

Rowland (1998) mendefinisikan bullying sebagai kekerasan jangka panjang, fisik atau psikologis, yang dilakukan oleh individu atau kelompok dan diarahkan terhadap individu yang tidak mampu membela diri. Adanya perbedaan kekuasaan dan bentukbentuk bullying yang bervariasi adalah unsurunsur yang disepakati oleh para ahli yang menjadi ciri khas bullying. Sejumlah penelitian telah mengeksplorasi penyebab bullying, meskipun hasilnya tidak sepenuhnya konsisten, beberapa variabel signifikan telah diidentifikasi (Olweus, 1978, Laeheem, Kuning, Mcneil, 2009). Penyebabnya dikategorikan sebagai faktor individu, faktor keluarga, faktor sosial budaya, faktor pengaruh kelompok, dan faktor sekolah.

1. Faktor Individu

Faktor individu termasuk di dalamnya kekuatan fisik dan reaksi agresif yang dimiliki pelaku bullying dan korban. Olweus (1978) menemukan bahwa secara fisik pelaku memiliki fisik yang kuat, sementara itu korban secara fisik lebih lemah. Tidak semua anak laki-laki kuat adalah pelaku bullying, hanya merek yang memiliki kecenderungan agresif yang memiliki potensi besar untuk menjadi pelaku. Kristi dan Fardana (2012) berpendapat bahwa individu yang memiliki keyakinan diri mampu secara optimal berperilaku kreativitas, baik itu dalam hal apapun.

Penelitian lain menunjukan bahwa era teknologi digital menjadi tantangan terbesar dalam yang menyebabkan individu diberikan kemudahan dalam askes informasi dan menerima konsekuensi dari dampak tersebut (Hendriani, 2017).

\section{Faktor Keluarga}

Peneliti lain telah menyelidiki dimensi fungsi keluarga, antara lain yakni adalah faktor gaya pengasuhan permisif, kurangnya keterlibatan dan kehangatan (Olweus, 1980), disiplin keras (Weiss, Dodge, Bates, \& Pettit, 1992), dan pengalaman kekerasan, semua tampaknya merupakan faktor keluarga yang relevan dalam melarkan pelaku bullying. Keluarga dari etnis Cina dikenal lebih otoriter daripada tipikal di negara-negara Barat. Ini mungkin menjelaskan tingginya prevalensi pelaku bullying di Hong Kong. Orang tua etnis Cina modern tidak seotoriter seperti pendahulu mereka, dan ada hukum di Hong Kong menentang penggunaan hukuman badan terhadap anak-anak. Orang tua memiliki peran dalam perkembangan emosi anak yang dapat membentuk pola perilaku dalam kehidupan sehari-hari (Hartini, Suminar \& Handoyo, 2001).

\section{Media Masa}

Derksen dan Strasburger berpendapat bahwa penyebab meningkatnya kekerasan pemuda terletak pada kekerasan yang ditayangkan media. Seseorang memiliki perasaan yang ingin diakui untuk memenuhi kebutuhan psikososial pada ruang media massa (Ardi, 2016). Mereka berpendapat bahwa pengaruh media sangat halus dan mendarah daging dari waktu ke waktu termasuk dalam kekerasan. Kekerasan selalu ditunjukkan sebagai cara penyelesaian konflik yang dapat diterima di media. Anak-anak dapat secara tidak sadar memodelkan perilaku yang tidak diinginkan (Bandura, Ross, \& Ross, 1963; Heusmann, 1982). Keterampilan berbicara meningkat Ketika individu mampu
Sigit Nugroho, Seger Handoyo, dan Wiwin Hendriani: Identifikasi Faktor Penyebab Perilaku Bullying Di Pesantren: Sebuah Studi Kasus 
memaksimalkan media saat ini (Muna, Degeng \& Hanurawan, 2019).

4. Faktor Teman Sebaya

Masa remaja adalah masa mencari identitas dan membentuk kelompok referensi mereka sendiri. Penelitian pada anak jalanan menunjukkan bahwa kelompok teman sebaya memiliki efek mendalam pada perilaku manusia (Spergel, 1967; Whyte; 1943). Tekanan kelompok, norma kelompok, dan identitas kelompok adalah faktor kunci yang berpengaruh terhadap perilaku teman sebaya. Arah pengaruh dari kelompok ke individu tidak hanya melalui satu cara. Penelitian telah menunjukkan bahwa orang paling sering memilih untuk bergabung dengan kelompok yang sesuai dengan dirinya; yang memiliki nilai dan sikap yang sama (Collins, Maccoby, Steinberg, Hetherington, \& Bornstein, 2000; Kass, 1999). Jadi faktor kelompok tidak dapat mengesampingkan bagian yang dimainkan oleh faktor individu (lam \&Liu, 2006).

Penelitian lain menunjukan seseorang remaja yang dapat menjalin hubungan yang baik dengan teman sebayanya mampu bekerja sama dengan baik dalam mengerjakan tugas sekolah dan begitu juga sebaliknya (Rasyid \& Suminar, 2012).

\section{Lingkungan sekolah}

Olweus (1993) menemukan bahwa jumlah guru yang ditugaskan untuk mengawasi waktu istirahat siswa secara negatif dikaitkan dengan jumlah insiden bullying. Peneliti lain fokus pada dampak iklim sekolah. Licata (1987) menunjukkan bahwa sikap positif di antara siswa dan staf dapat menyebabkan perilaku positif, sehingga mengurangi perilaku merusak.

Menilik konteksnya, penelitian perundungan pada awalnya banyak dilakukan di sekolah umum atau nonboarding. Padahal terdapat penelitian terdahulu yang menyatakan bahwa perundungan tidak hanya terjadi di sekolah umum, namun juga terjadi di sekolah asrama (Pfeiffer \& Pinquart, 2014; Edling \& Francia, 2017). Penelitian lain menyebutkan faktor lingkungan akademik mampu memediasi kontrak psikologis seseorang dalam melakuakan aktivitasnya (Suhariadi, 2018).

Sebuah penelitian percontohan pada sekolah asrama di Jerman, yang dilakukan oleh Pfeiffer dan Pinquat (2014) menemukan jika siswa-siswi yang belajar di sekolah asrama lebih sering menjadi pelaku perundungan dan sekaligus menjadi korban perundungan dibanding siswa siswi yang bersekolah di sekolah umum. Penelitian lain berupa survei deskriptif yang dilakukan oleh Muguve (2017) pada siswa sekolah dan anggota komite disiplin, di sebuah sekolah asrama se-tingkat SMU di Zimbabwe menemukan ada beberapa hal yang menjadi penyebab munculnya perundungan di sekolah asrama, yaitu: Pertama, kurangnya aturan sekolah mengenai perundungan $84 \%$ komite disiplin sekolah serta $97 \%$ siswa sekolah menyatakan setuju pada pernyataan kurangnya aturan sekolah menjadi penyebab munculnya perilaku perundungan di sekolah asrama. Ketika ditemukan adanya pelaku perundungan di sekolah, sekolah cendrung mengabaikan si pelaku. Tidak adanya aturan yang jelas bagi pelaku perundungan, akan memperkuat anggapan jika perundungan adalah hal yang wajar untuk dilakukan. Kedua, faktor personal dari pelaku dimana $40 \%$ siswa sangat setuju, $45 \%$ siswa setuju dan $42 \%$ anggota komite disiplin setuju jika pelaku perundungan bertujuan untuk mencari perhatian orang 
dewasa. Hal ini bisa terjadi karena pelaku merupakan pribadi yang kurang atau secara akademis dinilai tidak mampu. Perundungan merupakan kompensasi atas ketidakmampuan pelaku. Dengan menjadi pelaku perundungan, pelaku akan mendapatkan perhatian orang lain dan menjadi bahan pembicaraan, seolah-olah pelaku perundungan terlihat sebagai seorang pahlawan. Ketiga, faktor parenting atau pengasuhan anak yang dinilai kurang menjadi penyebab perundungan. Sekitar $30 \%$ siswa sangat setuju jika pengasuhan yang kurang optimal terhadap anak menjadi penyebab seseorang melakukan perundungan, sementara $35 \%$ siswa setuju mengenai hal ini. Sekitar $17 \%$ anggota komite disiplin sangat setuju jika pengasuhan yang kurang menyebabkan seseorang melakukan perundungan, sementara $42 \%$ komite disiplin setuju mengenai hal ini. Keempat, perundungan dapat terjadi karena pelaku sering menghabiskan waktunya dengan melihat atau menonton film yang mengandung kekerasan fisik. Sebanyak $28 \%$ siswa sangat setuju mengenai hal ini dan $35 \%$ setuju dengan ini, sementara $42 \%$ komite disiplin sangat setuju dengan hal ini dan $25 \%$ komite sekolah setuju.

Para korban umumnya mengalami perundungan verbal. Beberapa siswa melaporkan tindakan perundungan di sekolah asrama terjadi tanpa henti, mengingat target korban memiliki sedikit pilihan untuk menghindar dari pelaku di asrama (Schaverian, 2004). Hal ini diperkuat oleh temuan Donaldson \& Poynting (2005), yang menyatakan tindakan perundungan berupa ejekan karena isu ras dan seksual biasa terjadi dan telah mengakar di sebuah sekolah asrama di Australia. Perundungan verbal berupa ejekan yang ditujukan kepada junior dianggap sebagai ritual penyambutan yang wajar bagi warga asrama yang baru bergabung (Schaverian, 2004). Adanya persaingan antara siswa yang tinggal di asrama juga menjadi pemicu perundungan di asrama (Pfeiffer \& Pinquart, 2014). Edling dan Francia (2017), mendefinisikan kekerasan yang terjadi di sekolah asrama dengan istilah boarding school syndrome. Istilah ini merujuk pada berbagai kekerasan yang rentan dialami pelajar, seperti perundungan, pelanggaran dan gangguan.

Berdasar beberapa data di atas, sekolah berasrama memiliki kerentanan untuk terjadinya tindak perundungan dibandingkan sekolah umum. Tinggal di sekolah berasrama diasosiasikan dengan perpisahan dengan orangtua, berinteraksi dengan teman dalam jangka waktu yang lama dari proses belajar di kelas sampai aktivitas tidur (White, 2004). Penelitian yang dilakukan Pfeiffer dan Pinquart (2014) menemukan banyaknya waktu yang dihabiskan dengan teman-teman di asrama, memungkinkan perundungan lebih sering terjadi di asrama. Kurangnya pengawasan orangtua dan pengawas asrama membuat interaksi antar siswa tidak terpantau. Selain karena faktor pengawasan, Walford (2009) menyebutkan bahwa siswa yang masuk di sekolah berasrama memiliki latar belakang yang rentan untuk terlibat dalam perilaku perundungan. Beberapa siswa yang terlibat perundungan pada sekolah berasrama, perilakunya dibentuk dari rumah seperti siswa korban perceraian orangtua, mereka sengaja dimasukkan ke sekolah berasrama untuk mengurangi efek dari permasalahan keluarga tersebut.
Sigit Nugroho, Seger Handoyo, dan Wiwin Hendriani: Identifikasi Faktor Penyebab Perilaku Bullying Di Pesantren: Sebuah Studi Kasus 


\section{METODE PENELITIAN}

Jenis penelitian ini menggunakan metode kualitatif pendekatan studi kasus dengan teknik analisis tematik. Analisis tematik adalah cara mengidentifikasi tematema yang terpola dalam suatu fenomena. Tema-tema ini dapat diidentifikasi, dikodekan secara induktif dari data kualitatif maupun secara deduktif berdasarkan teori maupun hasil penelitian terdahulu (Boyatzis, 1998). Dalam penelitian ini penulis menggunakan pendekatan deduktif (theory driven). Responden penelitian merupakan alumni pesantren sebanyak 4 orang. Responden berkisar antara 1-3 tahun sebagai alumni pesantren. Semua responden pernah mengalami perilaku bullying sekaligus menjadi pelaku bullying.

Mengenai topik yang akan diteliti yakni penyebab perilaku bullying di pesantren digunakan teori Rowland (1998) yakni aktor individu, keluarga, media massa, teman sebaya dan lingkungan sekolah. Tema pada faktor individu yakni fisik yang kuat dan kecenderungan agresif. Tema pada faktor keluarga meliputi gaya pengasuhan permisif, kurangnya keterlibatan, kehangatan, disiplin keras, dan pengalaman kekerasan. Tema pada faktor media massa adalah kekerasan yang ditayangkan media. Tema pada faktor teman sebaya adalah tekanan kelompok, norma kelompok, dan identitas kelompok. Tema pada faktor lingkungan sekolah adalah iklim yang terdapat di sekolah.

Data diperoleh dengan wawancara semi terstruktur menggunakan panduan wawancara yang dikembangkan untuk mengungkap tema-tema yang ada pada teori Rowland (1998) mengenai faktor-faktor penyebab bullying. Wawancara dilakukan oleh peneliti pada dua responden, dan pada dua responden yang lain yang dilakukan oleh asisten peneliti yang sudah dilatih sebelumnya.

\section{HASIL PENELITIAN}

Dari hasil penelitian diperoleh tematema mengenai penyebab bullying yang sesuai dengan teori yang digunakan. Yang pertama adalah faktor individu. Para responden yang melakukan bullying diidentifikasi memiliki kecenderungan agresif. Hal ini tampak pada wawancara pada subjek AA, sebagai berikut; "Terkadang saya menjadi, pribadi yang tenang, ketika memang saya harus diam yaa diam, tapi tiba saatnya saya untuk agresif saya jadi agresif gitu, atau mungkin teman-teman menyebut saya ini lasak atau bandel gitu" (WSU12111AA baris 126-130).

Orang-orang dengan memiliki sifat agresif cenderung akan melakukan perilaku bullying, apalagi jika memiliki fisik yang kuat (Lam \& Liu, 2007, Neto, 2005) biasanya perilaku agresif ini muncul dari anak yang lama menjadi korban bullying (Sigurdson, Undheim, Wallander, Lydersen, \& Sund, 2015).

Dalam penelitian ini tidak ditemukan tema mengenai fisik yang kuat cenderung melakukan bullying. Hal ini terkonfirmasi dari hasil observasi bahwa fisik responden tidak dalam katagori fisik yang besar (kuat). Bahkan dari keterangan responden MAF dinyatakan bahwa anak-anak yang "bagak" atau berlagak kuat akan cenderung diganggu jika dia adalah anak baru. Hal ini sesuai data "satu lagi bisa jadi yang kami beli itu anak-anak yang ibaratnya sok sok bagak lah dipesantren itu gini-gini di pesantren itu ibaratnya itu baru masuk tapi udah sok" (WSU22611MAF baris 
313-315). Anak dianggap berlagak kuat ditandai dengan karakteristik fisiknya.

Tema berikutnya adalah tentang pola asuh. Bullying dipengaruhi oleh pola asuh otoriter dan melakukan kekerasan. Pola asuh yang keras dialami oleh responden, terlihat dari hasil wawancara pada responden AA dan MAF, sebagai berikut;

"Kalau dikerasi orang tua waktu kecilnya saya sering dikerasi waktu itu pernah saya waktu itu mau mandi di laut itu kira-kira umur saya 5, 6 tahun Saya mandi di laut terus tahu-tahunya pas Saya mau naik dari atas ke atas orang tua saya datang membawa kayu yang kira-kira besar paralon itu ya paralon untuk kabel kabel itu jadi kan itu mukul saya gitu sampai patah. ya itu tadi dimarahin sama orang tua gitu" (WSU12111AA baris 94-103).

"Ketika saya masih kecil jadi seandainya kalau saya tak sholat wajib itu bapak saya paling marah jangan kan untuk tidak salat kadang saya tidak datang ke masjid Saya kadang Bapak saya bisa kamu saya dulu kerap mendapatkan perilaku yang kasar sama orang tua saya kadang juga Saya Sadari perilaku sayang dulu sangat susah diatur pada kan waktu dulu itu Perilaku saya waktu kecil itu sering main PS kadang lupa waktu waktu ibaratnya jam sekian harus sekolah tapi kadang saya tidak ingat dan malah asyik main PS kadang saking kesalnya saya tidak bisa diatur kadang Bapak saya sampai pernah menampar saya pernah ibadratnya memukul saya waktu itu dan sebagainya lah tapi itu ibaratnya eeee setelah" (WSU22611MAF baris 163-176).

Dua diantara responden yakni AA dan MAF mengaku memilih pesantren karena paksaan orang tuanya berdasarkan pengakuaanya ketika ditanya alasan masuk pesantren. Dengan data sebagai berikut; "Dipaksa sama orang tua", (WSU22611MAF baris 207). "pas SD karena saya bandel jadi saya dimasukkan ke pesantren" (WSU12111AA baris 135-136).

Terdapat penelitian yang menyebutkan bahwa pola asuh otoriter dan keras menjadi prediktor terhadap munculnya pada anak di masa akan datang. Studi longitudinal yang dilakukan oleh Rajendran, Kruszewski dan Halperin (2015) menunjukkan bahwa anakanak yang memiliki masalah gangguan perilaku agresif dengan yang tidak mengalami memiliki pola pengasuhan yang berbeda. Anak-anak yang memiliki masalah gangguan perilaku dibesarkan oleh gaya pengasuhan otoriter sedangkan anak yang tidak memiliki gangguan perilaku dibesarkan dengan gaya pengasuhan yang penuh kehangatan. Penelitian senada oleh Lam \& Liu (2006) menyatakan bahwa pola asuh orang tua yang melakukan kekerasan adalah prediktor yang konsisten dalam memprediksi perilaku bullying pada anak.

Teman sebaya sangat berpengaruh terhadap munculnya perilaku bullying di pesantren. Tindakan bullying yang dilakukan oleh senior semuanya dilaporkan oleh keempat responden sebagai penyebab yang utama bertahannya perilaku bullying di pesantren. Data-datanya sebagai berikut;

"Melakukan bullying itu berkelompok karena kalau sendiri kami tidak berani karena istilahnya kami itu tak mau mengambil resiko juga kalau sendiri kalau sendiri kan nanti Seandainya anak tadi itu melapor ke pengurus pastinya kami sendiri bakalan kena tapi kalau misalnya kami beramai-ramai dalam artian sakitnya itu bisa dirasakan beramai-ramai dan tidak begitu malu sekali Kalau misalnya ramairamai tapi kan kalau sendiri kan pasti lah kita nanggung Malu sendiri apalagi kalau nanti sampai dilihat sama orang yang kita kenal di tengok sama Ustad kita saudara-saudara kita pasti badannya begitu malu sekali tapi kan
Sigit Nugroho, Seger Handoyo, dan Wiwin Hendriani:

Identifikasi Faktor Penyebab Perilaku Bullying Di Pesantren: Sebuah Studi Kasus 
Kalau ramai-ramai mungkin ibaratnya masih adalah rasa malu kita ibaratnya Ndak begitu malu lah rasanya kalau seandainya nanti kenapa-napa kan gitu" (WSU22611MAF baris 264-279).

"Sayakan masih kebawa niih sifat-sifat waktu SD yang nakal lasak terus itu yang dilakukan bully kalau di pesantren waktu itu, itu dari Kakak kakak tingkat yang mudah merasa senior yaitu jadi dia yang melakukan hal-hal semenamena melakukan bully terhadap kami yang baru baru masuk sehingga Kami merasa apa $y a$, di tindas diintimidasi sama kakak kakak senior" (WSU12111AA baris 137-144).

"itu sangsinya dilabrak. Istlahnya orang jawa tuh dilabrak. Gimana ya. Kaya didatangi rame rame trus dimaki maki gitu. Kalo dijawa ya bilangnya dilabrak. Trus disindir sindir sampe kadang kalo junior yang ga betah itu sampe boyong. Boyong itu pindah dari pondok" (WSU32011S baris 91-96).

"Ada pasti ada dari zaman baholak pasti ada kayak mana pun kayak gitu pasti awal-awal kita masuk situ pasti kita ditindas dululah jangankan orang lain kita aja bisa jadi senioritas" (WSU42311I baris 127-130).

Data-data tersebut menunjukan bahwa senioritas menjadi faktor utama yang memunculkan perilaku bullying. Hal ini relevan dengan penelitian terdahulu, bahwa senioritas yang diasosiasikan dengan memiliki kekuasaan atau power mendorong orang untuk melakukan abuse (Olweus, 1978, Rigby, 2002).

Tema berikutnya adalah pengaruh media massa terhadap munculnya perilaku bullying. Dari penjelasan responden, AA dari MAF responden mengaku terinspirasi perilaku bullying dari tontonan yang mereka lihat. Pada subjek pertama AA tayangan smackdown menginspirasi untuk melakukan bullying. "Yaaa itu jadi saya itu karena postur badan kecil jadi saya kaya ngefans sama Rey
Mysterio. Kalau untukfilm yang agresif yaa itu film smackdown, naah untuk membully itu saya lihat lingkungan" (WSU12111AA baris 115119), sedangkan pada responden MAF, tayangan game PS Grand Theft Auto (GTA) dan Bully Game menjadi inspirasi responden melakukan bullying di pesantren, sebagai mana data berikut;

"Ada salah satu game PS yang paling sangat tenar itu namanya GTA itu adalah semacam game yang mana gangster lah Di mana perang antar wilayah geng sama geng satu lagi ada juga namanya bully, itu adalah game dimana anak nakal dimasukkan kedalam asrama dimana dia ingin menjadiketua diasrama itu. Jadi mukin kami juga termotivasi dengan game-game seperti itu maka ketika zaman saya itu juga pak, banyak dulu namanya geng-geng segala macamnya mulai dari anak-anak SMP sampai ke anak SD sudah banyak saya temukan itu (WSU22611MAF baris 183-194).

Penelitian-penelitian yang sudah dilakukan mengenai kekerasan media yang mempengaruhi perilaku bullying. Siswa yeng terpapar tontonan kekerasan memiliki hubungan dengan perilaku bullying yang dilakukan di sekolah (Lee \& Kim, 2007) dan terlibat kekerasan atau tindak kejahatan di masa depan (Anderson \& Huesmann, 2007). Penelitian lain adanya hubungan antara kekerasan pada video games, televise dan film dengan perilaku agresi dan kekerasan di dunia nyata (Anderson et al. 2003).

Pada tema pengaruh lingkungan sekolah, muncul dalam bentuk kurangnya pengawasan kejadian bullying di malam hari dan adanya sistem seperti mata-mata (jasus) mendorong untuk terjadinya perilaku bullying. Bullying terjadi pada area-area yang tidak ada pengawasan pengurus pesantren. Respon AA, MAF dan I mengaku bahwa asrama menjadi
Sigit Nugroho, Seger Handoyo, dan Wiwin Hendriani: Identifikasi Faktor Penyebab Perilaku Bullying Di Pesantren: Sebuah Studi Kasus 
tempat yang lazim terjadi bullying. Dengan data wawancara responden sebagai berikut; Nah dulu itu aku tuh gini ada orang yang enggak suka sama aku terus tau Jasus nggak di jasus itu kalau nama bahasa Arab Kalau bahasa Indonesianya artinya mata-mata dulu kan diterapkan namanya itu bahasa Arab dan bahasa Inggris dan bahasa Indonesia jadi ibaratnya itu hari ini dipanggil besok dipanggil jadi orang itu kayak dendam gitu sama aku dan itu aku tahu Baru tahu ketika aku kelas 2 SMP kelas 2 MTS gitu kau kunci kamarnya dulu yang ngasih tahu sama aku ya apa namanya kau kok nggak pernah marah ya itu loh Benci kali sama kau sampai dulu kau dulu pernah sering di gini sering kena panggil sama anak bahasa kau dulu pernah sempat kena malu-maluin dibanding cowok terus kau ni malu-maluin. Terus duit kau habis kau disuruh ini itu Iya ingat kali aku loh terus dia yang chat aku ya aku kok nggak pernah marah ya ya Kayak mana aku mau marah Aku nggak tahu Orangnya siapa yang chat-an aku kayak gitu tapi ya kayak gimana lah lagi tapi kayak mana ya emang aku nggak bisa marah Orangnya sama dia Entahlah sifat aku yang pendiam atau gimana tak tahulaah aku do (WSU42311I baris 134153).

Jarang, ustadznya taunya itu dari kakak-kakak tingkat atau namanya kalo dipesantren itu ada namanya jasus atau mata-mata jadi dia nunggu laporan dari jasus sedangkan mata-mata ini tadi yang melakukan bully tadi (WSU12111AA baris 196-200).

"Terjadi rata-rata ketika malam hari selesai adanya belajar wajib Jadi kami di pesantren itu setelah selesai sholat isya kami ada kegiatan namanya belajar wajib itu boleh kami belajar sekolah formal untuk sekolah formal Bolehkan pelajar untuk Sekolah Diniyah jadi selesai jam 10.00 itu kami itu kami sampai malam sampai jam 12.00 malam habisya kami mulai mulai melakukan hal seperti itu ketika selesai namanya belajar wajib kadangpun ketika belajar wajib kamipun melakuakan hal itu ketika tidak ada yang mengawasi kan biasanya kami iseng-iseng datang datang ke tempat anak baru yang kira-kira bisa lah kami manfaatin ketika itu” (WSU22611MAF baris 144-15).

Tema yang muncul pada faktor individu yang belum dijelaskan adalah faktor adaptasi terhadap lingkungan baru. Siswasiswa yang kurang mampu beradaptasi akan cenderung di bullying oleh senior karena dianggap tidak berperilaku sesuai dengan para senior. Bentuknya perilaku adalah menantang terhadap senior, terlalu lugu dan menampilan diri memiliki potensi. Sebagaimana data yang disampaikan oleh responden MAF yakni sebagai berikut;

Ketika saya sudah menjadi pelaku pembullyan itu bukannya ingin ada balas dendam sih pak ibaratnya karena seperti tadi saya bilang seperti sebuah tradisi karena kita merasa senior menjadi penguasa jadi seakan-akan itu hal yang perlu kita kerjakan kita itu satu candaan jadi tanpa Saya Sadari saya tak pernah mengingat lagi bagaimana masa lalu keyika saya dibully tapi itu ingin saya lakukan ibaratnya hanya untuk becanda jadi ketika anak baru masuk tanyain istilahnya mana yang tidak tahu karena saya bodoh bodoh segala macamnya bagi saya ketika itu adalah suatu candaan baris (WSU22611MAF baris 104115).

Tema lain adalah persepsi mengenai perilaku bullying. Bullying dianggap biasa karena sebatas dianggap sebagai candaan dan cara bermain. Bullying dipersepsi sebagai perilaku bercanda dan merupakan perilaku yang wajar terjadi, dan perkataan ini diulang beberapa kali oleh responden MAF menunjukkan bahwa persepsi bullying sebagai cara bercanda cukup kuat. Hal itu ditunjukan dari hasil wawancara dengan responden MAF sebagai berikut; "Karena kan gini pak kebanyakan orang orang itu kalau bercanda itu nggak pernah mikir batasan yang penting
Sigit Nugroho, Seger Handoyo, dan Wiwin Hendriani: Identifikasi Faktor Penyebab Perilaku Bullying Di Pesantren: Sebuah Studi Kasus 
apa yang dikerjakan puas dihati" (WSU22611MAF baris 31-33). "Kami bercanda yakan awal-awal Cuma guyonan" (WSU22611MAF baris 50-51). "Pesantren mungkin hal itu ada hal yang lumrah biasa untuk digunakan bercanda tapi mungkin pandangan Bagaimana orang luar tetapi kami tak tahu kan haa Jadi kami rasa itulah ada bagi kami ketika masih menjadi anak pesantren itu itu bukanlah satu hal pembullyan bagi kami itu hal yang lumrah gitu" (WSU22611MAF baris 55-60). “....senior kadang juga saya ditanyain selanya dicandak mungkin bagi mereka itu adalah suatu percandaan". (WSU22611MAF baris 9093). "....jadi seakan-akan itu hal yang perlu kita kerjakan kita itu satu candaan (WSU22611MAF baris 108-109). Selain hal tersebut, bullying juga dianggap sebagai tradisi yang biasa atau normal terjadi di pesantren, dengan data dari responden MAF sebagai berikut; "Saya menjadi korban pembullyan yang mungkin karena itu seperti seakan-akan sudah menjadi tradisi di pondok pesantren" (WSU22611MAF baris 15-17). Bahkan yang lebih menyedihkan responden yang bersangkutan menyebutkan bahwa melakukan bullying adalah alternatif hiburan ditengah padatnya aktivitas belajar dan minimnya fasilitas hiburan seperti menonton televisi;

"Kami kerjakan itu semua terbatas dari mulai Kami menggunakan fasilitas seperti yang kirakira menghibur seperti nonton TV Kami nonton $T V$ di pesantren itu hanya dibolehkan Pada saat jam makan siang dan itupun kira-kira tidak sampai 1 jam dan selebihnya kami hanya terus belajar terus belajar terus sekolah jadi mungkin karena saat itulah karena tidak ada hiburan dan apa yang bisa kami kerjakan begitulah jadinya hiburan yang bisa kami laksanakan untuk menghibur diri lah Mungkin kira-kira menurut saya seperti itu karena mungkin tertekan dengan kegiatan yang full pada di pondok akan hal seperti itu maka kami lakukan hal seperti itu" (WSU22611MAF baris 247-259).

\section{SIMPULAN}

Dari tema-tema penyebab bullying berdasarkan pada pendapat yang dikemukakan Rowland (1998) semua tema ditemukan dari hasil wawancara dengan responden. Kelima faktor penyebab bullying yakni faktor individu, keluarga, media massa, teman sebaya dan lingkungan sekolah muncul dalam tematema yang disampaikan responden terutama pada responden AA dan MAF. Tiga tema yakni adaptasi siswa baru, persepsi terhadap perilaku bullying yang dianggap sebagai candaan dan tradisi pesantren serta bullying sebagai kompensasi mencari hiburan di pesantren karena padatnya aktivitas belajar dan minimnya fasilitas belajar adalah tema baru yang muncul di luar dari tema teoritik. Saran untuk peneliti selanjutnya agar dapat memperluas responden penelitian bukan hanya pada pelaku saja dan menggunakan obeservasi sebagai alat pengumpul data tambahan.

\section{DAFTAR PUSTAKA}

Anderson, C. A., \& Huesmann, L. R. (2007). Human aggression: A social- cognitive view. In M. A. Hogg \& J. Cooper (Eds.), The sage handbook of social psychology (pp. 259-287). London: Sage Publications.

Anderson, Craig A.; Berkowitz, Leonard; Donnerstein, Edward; Huesmann, L. Rowell; Johnson, James D.; Linz, Daniel; Malamuth, Neil M.; Wartella, Ellen (2003). "The influence of media violence on youth". Psychological Science in the Public Interest.

Sigit Nugroho, Seger Handoyo, dan Wiwin Hendriani: 
Ardi, R. (2016). Anonimitas dan Pemenuhan Kebutuhan Psikososial melalui Pengungkapan Diri di Media Sosial. In H. P. Indonesia, Psikologi dan Teknologi Informasi (pp. 379-400). Jakarta: Himpunan Psikologi Indonesia

Bandura, A., Ross, D., \& Ross, S. A. (1963). Imitation of film-mediated aggressive models. Journal of Abnormal and Social Psychology, 66, 3-11.

Bawani, I. (1993). Tradisionalisme dalam pendidikan Islam: studi tentang daya tahan pesantren tradisional. Al-Ikhlas.

Boyatzis RE. (1998). Transforming Qualitative Information. Sage: Cleveland

Collins, W. A., Maccoby, E. E., Steinberg, L., Hetherington, E. M., \& Bornstein, M. H. (2000). Contemporary research on parenting: The case for nature and nurture. American psychologist, 55(2), 218.

Derksen, D. J., \& Strasburger, V. C. (1996). Media and Television Violence: Effects on Violence, Aggression, and Antisocial Behaviors in Children (From Schools, Violence, and Society, P 62-77, 1996, Allan M Hoffman, ed.-See NCJ170982).

Desiree. (2012). Bullying di pesantren. Jurnal Psikologi. FSIP_UI Dolby, R. (2011). About bullying. Every Child, 17(1), 33.

Donaldson, M., \& Poynting, S. (2005). Snakes and leaders: Hegemonic masculinity in ruling-class boys' boarding schools. Men and Maculinities, 7, 325-346.

Edling, S., \& Francia, G. (2017). Children's rights and violence: A case analysis at a Swedish boarding school. Sage Journal, 24, 51-67. Doi: https://doi.org/10.1177/0907568216634 063

Finiswati, E., \& Matulessy, A. (2018). Kecendrungan melakukan bullying ditinjau dari jenis kelamin dan urutan kelahiran pada santri di Pondok
Pesantren. Fenomena: Jurnal Psikologi, 1, 13-23.

Hartini, H. M., Suminar, D. R., \& Handoyo, S. (2001). Peran Pola Permainan Sosial Dalam Meningkatkan Kecerdasan Emosi Anak. Jurnal Penelitian Dinamika Sosial, 2(1), 66-72

Hendriani, W. (2017). Menumbuhkan Online Resilience pada Anak di Era Teknologi Digital. Prosiding Temu Ilmiah Nasional $X$ Ikatan Psikologi Perkembangan Indonesia, 1 .

Heusmann, H. W., \& Bellville, R. H. (1982). Wood Duck research in Massachusetts, 1970-1980. Massachusetts Division of Fisheries and Wildlife, Westborough, Massachusetts.

Kass, S. (1999). Bullying widespread in middle school, say three studies. APA Monitor, 30(9), 1-2.

Kisti, H. H., \& Fardana, N. A. (2012). Hubungan antara self efficacy dengan kreativitas pada siswa SMK. Jurnal Psikologi Klinis dan Kesehatan Mental, 1(02), 52-58.

Laeheem, K., Kuning, M., \& McNeil, N. (2009). Bullying: Risk factors becoming 'Bullies'. Asian Social Science, 5(5), 50 57.

Lam, D.O.B \& Liu, A.W.H. (2007). The path through bullying-A process model from the inside story of bullies in Hong Kong secondary schools. Child and Adolescent Social Work Journal, 24.

Lee \& Kim (2007). Exposure to media violence and bullying at school: mediating influences of anger and contact with delinquent friends. J Adolesc Health. 2007 Dec; 41(6 Suppl 1): S6-13.

Licata, V. F. (1987). Creating a positive school climate at the junior high level. Paper presented at the Annual Meeting of the Michigan Association of Middle School Educators. Birmingham, A.L
Sigit Nugroho, Seger Handoyo, dan Wiwin Hendriani: Identifikasi Faktor Penyebab Perilaku Bullying Di Pesantren: Sebuah Studi Kasus 
Marthunis., \& Authar, N. (2017). Bullying at Aceh modern islamic boarding school (Pesantren) Teacher's perceptions and inverventions. Sukma: Jurnal Pendidikan, 1, 219-248.

Muguve, K. (2017). Causes of bullying in boarding high school in Zimbabwe. International Journal of Scientific and Research Publication, 7, 652-657.

Muna, E. N., Degeng, I. N. S., \& Hanurawan, F. (2019). Upaya Peningkatan Keterampilan Berbicara Menggunakan Media Gambar Siswa Kelas IV SD. Jurnal Pendidikan: Teori, Penelitian, dan Pengembangan,4(11), 1557-1561.

Neto, A. A. (2005). Bullying- aggressive behaviour among students. Journal de Pediatria. Brazilian Multi-professional Association for Children and Adolescent Protection

Nugroho, S., \& Fardhana, N.A. (2018). Bullying at islamic boarding school: A pilot study in Pekanbaru. International Journal Of Pure And Applied Mathematics, 199, 2095-2100.

Olweus, D. (1978). Aggression in the schools: Bullies and whipping boys. Washington, DC: Hemisphere.

Olweus, D. (1980). Familial and temperamental determinants of aggressive behavior in adolescent boys: A causal analysis. Developmental Psychology, 16, 644-660.

Olweus, D. (1993). Bullying at school: What we know and what we can do. Oxford: Blackwell. Orpinas, P., \& Horne, A. M. (2006). Bullying prevention: Creating a positive school climate and developing social competence. Washington, DC: American Psychological Association.

Olweus, D., (1978) Aggression in the schools. Bullies and whipping boys.

Pfeiffer, J.P., \& Pinquart, M. (2014). Bullying in German boarding school: A pilot study. School Psychology International, 35, 580-591.

Rajendran, K., Kruszewski, E., \& Halperin, J. (2015). Parenting style influences bullying: A longitudinal study comparing children with and without behavioral problems. Journal of Child Psychology and Psychiatry, 57(2), 188-19.

Rasyid, M., \& Suminar, D. R. (2012). Hubungan antara peer attachment dengan regulasi emosi remaja yang menjadi siswa di boarding school SMA Negeri 10 Samarinda. Jurnal psikologi pendidikan dan perkembangan, 1(3), 17.

Rigby, K. (2002). New Perspectives on Bullying. Jessica Kingsley: London.

Rowland, I. D. (1998). The culture of the High Renaissance: ancients and moderns in sixteenth-century Rome (p. 101). Cambridge: Cambridge University Press.

Schaverian, J. (2004). Boarding school: The trauma of the 'privileged' child. Journal of Analytical Psichology, 45, 683-705. Schneider, F., Gruman, J., \& Coutts, L. (2012). Applied social psychology. Understanding and addressing social and practical.

Sigurdson, J. F., Undheim, A. M., Wallander, J. L., Lydersen, S., \& Sund, A. M. (2015). The long-term effects of being bullied or a bully in adolescence on externalizing and internalizing mental health problems in adulthood. Child and Adolescent Psychiatry and Mental Health, 9, Article 42.

Simbolon, M. (2012). Perilaku bullying pada mahasiswa berasrama. Jurnal Psikologi, 39. 233-243.

Spergel, M. S. (1967). MS Spergel, Nuovo Cimento 47A, 410 (1967). Nuovo Cimento, 47, 410.

Suhariadi, F. (2019). Kontrak psikologis terhadap commitment to change: 
Resiliensi akademik sebagai variabel mediasi. Persona: Jurnal Psikologi Indonesia, 8(2), 178-192.

Suteja. (1999). "Pola Pemikiran Kaum Santri: Mengaca Budaya Wali Jawa", dalam Marzuki Wahid.et.all. (ed.), Pesantren Masa Depan: Wacana Pemberdayaan dan Transformasi Pesantren (Bandung: Pustaka Hidayah), hlm. 77.

Walford, G. (2009). Private schools in England. Zeitschrift fu Pa dagogik, 55, 716-731.

Wang, C., Berry, B., \& Swearer, S. M. (2013). The critical role of school climate in effective bullying prevention. Theory Into Practice, 52, $296-302$. http://dx.doi.org/10.1080/00405841.201 3.829735

Washnigton D.C., Hemisphere press (Wiley).

Weiss, B., Dodge, K. A., Bates, J. E., \& Pettit, G. S. (1992). Some consequences of early harsh discipline: Child aggression and a maladaptive social information processing style. Child development, 63(6), 1321-1335

White, M.A. (2004). An Australian coeducation boarding school as a crucible for life: A humanistic sociological study of students' attitudes from their own memoirs. Unpublished dissertation, University of Adelaide.

Whyte, J. (1943). American Words and Ways, Especially for German Americans. Viking Press.

Yani, A.L., Winarni, A., Lestari, R. (2016). Eksplorasi fenomena korban bullying pada kesehatan jiwa remaja di pesantren. Jurnal Ilmu Keperawatan, 4, 93- 113.

Ziemek, M. (1986) Pesantren Dalam Perubahan Sosial, Jakarta: P3M. 